\title{
IMPLIKASI MEDIASI DALAM PERKARA PERDATA DI PENGADILAN NEGERI TERHADAP ASAS PERADILAN SEDERHANA, CEPAT, DAN BIAYA RINGAN
}

\author{
Netty Herawati \\ Fakultas Hukum Universitas Islam Kadiri Kediri \\ e-mail:netty_uniska@yahoo.co.id
}

\begin{abstract}
ABSTRAK
Penyelesaian sengketa perdata di pengadilan negeri dengan asas peradilan sederhana, cepat, dan biaya murah, maka diharapkan dapat diselesaikan melalui proses perdamaian dengan menggunakan mediasi agar tidak terjadi penumpukan perkara. Sejak diberlakukannya Peraturan Mahkamah Agung Nomor 1 Tahun 2008 telah diefektikan proses penyelesaian mediasi sebagai alternatif penyelesaian sengketa. Dalam ketentuan PERMA Nomor 1 Tahun 2008, tahap mediasi dalam proses penyelesaian sengketa perdata di pengadilan negeri bersifat hukum memaksa. Proses mediasi ini membutuhkan waktu sehingga kalau tidak berhasil, maka baru dilakukan proses penyelesaian sengketa perdata secara litigasi. Waktu yang dibutuhkan akan mengganggu penerapam asas peradilan sederhana, cepat, dan biaya murah, terlebih lagi jarang terjadi keberhasilan penyelesaian sengketa dengan cara mediasi. Sedangkan menurut HIR, kemungkinan untuk dilakukan penyelesaian sengketa perdata secara perdamaian bisa dilaksanakan sepanjang proses pemeriksaan sengketa perdata.
\end{abstract}

Kata Kunci: mediasi, asas peradilan.

\begin{abstract}
The settlement of law court dispute in district court simply, rapidly and economically judicature principle hoped be able to settle through the peaceful process with mediation in order that it is not overloaded the case. Since it has been done The rule of High Court of Justice No. 1/2008 it has been effective the process of mediation settlement as an alternative of settlement dispute. In PERMA No. 1/2008 the mediation phase in the process of the settlement of law court dispute in district court is being law of force. The process of the mediation needs much time so if it is not successful, it will be done the process of law court settlement legitimately. The time needed will disturb the implementation of simply, rapidly and economically judicature principle, moreover it has not been successful. While based on HIR, it may be done the settlement of law court dispute peacefully during the law court inspection.
\end{abstract}

Keywords: mediation, judicature principle.

\section{PENDAHULUAN}

Negara Indonesia didirikan oleh para pendiri bangsa dengan cita-cita menegakkan negara berdasarkan hukum dan ditegaskan dalam UndangUndang Dasar (UUD) 1945 Pasal 27 ayat (1) bahwa "Segala warga negara bersamaan kedudukannya di dalam hukum dan pemerintahan dan wajib menjunjung hukum dan pemerintahan itu dengan tidak ada kecualinya". Berdasarkan Pasal 27 ayat (1) UndangUndang Dasar 1945 menunjukkan negara memberikan jaminan persamaan kedudukan setiap warga negara di depan hukum. Jaminan yang dimaksud adalah keadilan bagi seluruh rakyat Indonesia dengan tidak ada lagi pembedaan-pembedaan (non-discrimination) dan bersifat universal. Namun setelah lebih dari 65 tahun kemerdekaan, dan 13 tahun setelah memasuki era reformasi harapan masyarakat Indonesia terhadap upaya penegakan hukum di Indonesia cenderung semakin apatis. Tingkat kepercayaan masyarakat terhadap proses penegakan hukum semakin berkurang.

Penegakkan hukum di Indonesia yang masih lemah, menyebabkan masyarakat menjadi penat dan mempengaruhi cara pandang terhadap hukum dan penegakan hukum sebagai benteng keadilan. Akibatnya, banyak orang berusaha menghindari lembaga peradilan jika hendak menyelesaikan sengketa dengan pihak lain. Penyelesaian sengketa 
melalui lembaga peradilan seringkali menimbulkan masalah baru, karena menang atau kalah ternyata tidak menenangkan hati. Biasanya orang yang telah bersengketa di lembaga peradilan, sekalipun sengketanya sudah diputuskan akan tetapi pertikaian antar pihak yang bersengketa terus berlanjut, seperti tidak bertegur sapa lagi dan tidak jarang saling menyimpan dendam berkepanjangan. Penyelesaian perkara di lembaga peradilan seringkali harus membutuhkan waktu yang lama. Dengan mengambil contoh pada sebuah sengketa suami istri atas harta gono gini di Pengadilan Agama.

Dalam sengketa perebutan harta gono gini tersebut, istri beranggapan semua harta suaminya adalah harta bersama, pada satu sisi suaminya menolak anggapan tersebut karena sebagian dari hartanya yang ada sekarang bukanlah harta bersama, karena sebagian didapatkan dari warisan orang tuanya. Karena sudah menyangkut sengketa milik, maka pengadilan agama tidak bisa memeriksa lebih lanjut tentang masalah itu. Masalah itu harus terlebih dahulu diselesaikan di pengadilan negeri. Oleh karena itu, hakim pengadilan agama yang memeriksa perkara itu akhirnya mempersilahkan pihak pengklaim (istri) agar mengajukan masalah sengketa milik itu ke pengadilan negeri sambil memberikan nasehat bahwa "sekiranya sepuluh tahun lagi umur kita masih panjang baru kita bertemu lagi, itupun jika anda mujur". Waktu sepuluh tahun itu, oleh hakim dirasionalisasi dengan cara mengemukakan bahwa suatu perkara di pengadilan negeri biasanya membutuhkan waktu 2 sampai 3 tahun, dan di Pengadilan Tinggi membutuhkan waktu 2 sampai 3 tahun dan waktu yang sama juga dibutuhkan untuk penyelesaian sengketa di tingkat kasasi. Hakim itu juga memperhitungkan lamanya waktu yang dibutuhkan jika para pihak itu mengajukan peninjauan kembali yang prosesnya juga tidak lebih cepat dari pengadilan biasa, jika tidak beruntung maka mungkin akan jauh lebih lama lagi dari yang diperkirakan (Yahya Harahap, 2005:171).

Apalagi seandainya banyak perkara yang tertumpuk di pengadilan, maka akan memakan waktu yang lama dan akhirnya dari lamanya waktu tersebut mengakibatkan biaya tidak sedikit. Hal ini akan bertentangan atau tidak cocok dengan azas yang dikenal dalam Hukum Acara Perdata yang berbunyi: "Peradilan dilaksanakan dengan sederhana, cepat dan biaya ringan". Dalam rangka mewujudkan proses sederhana, cepat dan murah, maka diaturlah upaya perdamaian yakni dengan cara mengintegrasikan proses mediasi di pengadilan. Hal ini diatur dalam Pasal 130 ayat (1) HIR (Herziene Indonesisch
Reglement) disebutkan bahwa: "Jika pada hari yang ditentukan itu, kedua belah pihak datang, maka Pengadilan Negeri dengan pertolongan Hakim Ketua mencoba akan memperdamaikan mereka" (Ropaun Rambe, 2006:245).

Pada ayat di atas sangat jelas keharusan Hakim Ketua Pengadilan Negeri untuk mengupayakan perdamaian terhadap perkara perdata yang diperiksanya. Dalam kaitannya ini hakim harus dapat memberikan pengertian, menanamkan kesadaran dan keyakinan kepada para pihak yang berperkara, bahwa penyelesaian perkara dengan perdamaian merupakan suatu cara penyelesaian yang lebih baik dan lebih bijaksana dari pada diselesaikan dengan putusan pengadilan, baik dipandang dari segi waktu, biaya dan tenaga yang digunakan (Sri Wadah dan Bambang Sutiyoso, 2007:92).

Dalam sistem hukum Indonesia ada beberapa alternatif penyelesaian sengketa di luar peradilan yang didasarkan pada Undang-Undang No. 30 Tahun 1999 tentang Alternatif Penyelesaian Sengketa. Alternatif-alternatif yang dapat dilakukan oleh pihak yang bersengketa antara lain: konsultasi, negoisasi dan perdamaian, mediasi, konsiliasi dan perdamaian, pendapat hukum oleh lembaga arbitrase, dan arbitrase.

Dari beberapa alternatif penyelesaian sengketa di luar pengadilan, mediasi merupakan alternatif terbaik, mengingat perkara perdata yang diajukan di 1 (satu) pengadilan tingkat pertama (baik Negeri maupun Niaga) untuk tiap tahunnya cukup banyak dengan bermacam-macam perkara perdata termasuk niaga maupun perkara pidana. Langkah perdamaian dalam penyelesaian perkara gugatan di pengadilan merupakan tahapan yang efektif dan efisien, yang bertujuan untuk menciptakan kondisi win-win solution karena kedua belah pihak yang bersengketa berada dalam persamaan kedudukan dengan tidak ada yang kalah maupun menang, melainkan menemukan hasil terbaik.

Dengan segala permasalahan yang ada dan telah mempertimbangkan banyak hal serta aspek yang melingkupinya, upaya penerapan azas sederhana, cepat dan biaya ringan ke dalam prosedur mediasi yang telah berlangsung menjadi suatu hal yang perlu dilakukan perbaikan, maka melalui fungsinya sebagai lembaga yang memiliki kekuasaan dan kewenangan dalam membuat peraturan, Mahkamah Agung telah memberlakukan Peraturan Nomor 1 Tahun 2008 tentang Prosedur Mediasi yang diintensifkan ke dalam prosedur berperkara di Pengadilan Negeri yang berlaku sejak 11 September 2003 dan direvisi menjadi 
Peraturan Mahkamah Agung No. 1 Tahun 2008 tentang Prosedur Mediasi di Pengadilan Mahkamah Agung Republik Indonesia, yang berlaku sejak 31 Juli 2008, yang merupakan landasan dalam praktek beracara untuk mengefektifkan alternatif penyelesaian sengketa dengan mengutamakan perdamaian kepada pihak-pihak yang bersengketa.

Berdasarkan uraian atas permasalahan yang dikemukakan di atas, maka menarik untuk dibahas tentang Implikasi Mediasi dalam Perkara Perdata berdasarkan Peraturan Mahkamah Agung No. 1 Tahun 2008 terhadap Asas Peradilan Sederhana, Cepat, dan Biaya Murah.

\section{RUMUSAN MASALAH}

Permasalahan yang hendak dikemukakan dalam tulisan ini adalah Apa implikasi mediasi dalam perkara perdata di pengadilan berdasarkan Peraturan Mahkamah Agung No. 1 Tahun 2008 terhadap asas peradilan sederhana, cepat, dan biaya murah.

\section{PEMBAHASAN \\ Penyelesaian Sengketa Perdata}

Pasca reformasi 1998, perkembangan politik badan peradilan telah menuju terwujudnya sistem badan peradilan yang merdeka sebagaimana dikehendaki sejak awal oleh UUD 1945. Bahkan dalam amandemen UUD 1945, telah dibentuk institusi baru dengan nama Mahkamah Konstitusi yang berfungsi mengawal konstitusi terutama dalam hal menjaga agar tidak bertentangan dengan konstitusi terutama dalam hal menjaga agar tidak lagi muncul peraturan perundang-undangan yang bertentangan dengan konstitusi.

Perubahan undang-undang melahirkan konsekuensi bahwa di samping ada Mahkamah Konstitusi yang berfungsi sebagai pengawal konstitusi, ada juga kekuasaan Mahkamah Agung yang membawahi badan Peradilan Umum, Peradilan Agama, Peradilan Militer dan Peradilan Tata Usaha Negara. Pemerintah juga membentuk komisi yang berfungsi sebagai pengawas terhadap perilaku badan-badan yang terkait dalam penegakan hukum, antara lain: Komisi Yudisial, Komisi Kejaksaan dan Komisi Kepolisian Nasional. Seiring dengan reformasi di lembaga-lembaga peradilan yang tidak lain untuk meningkatkan kepercayaan masyarakat terhadap lembaga peradilan yang ada, untuk memaksimalkan proses penyelesaian sengketa, maka dikembangkan alternatif penyelesaian sengketa (Alternative Dispute Resolution/ADR) yang merupakan pengembangan budaya dari masyarakat dalam upaya-upaya pe- nyelesaian konflik, yang kemudian diatur tentang pengembangan kelembagaannya melalui landasan hukum yaitu Undang-Undang No. 30 Tahun 1999 tentang Arbritase dan Alternatif Penyelesaian Sengketa, walaupun di dalam undang-undang tersebut tidak mengatur bagaimana jika kesepakatan Alternative Dispute Resolution (ADR) tersebut ternyata kemudian hari diingkari oleh salah satu pihak (hanya sanksi sosial). Model penyelesaian konflik melalui ADR di Indonesia bukan barang yang baru lagi karena sudah membudaya dan lama dipraktekkan oleh masyarakat dalam penyelesaian sengketa. Pada masyarakat Amerika Serikat, banyak sekali pengusaha yang lebih memilih menyelesaikan sengketa kontrak di luar pengadilan (Alternative Dispute Resolution (ADR).

Beberapa bentuk penyelesaian sengketa di luar peradilan berdasarkan Undang-Undang No. 30 Tahun 1999 tentang Alternatif Penyelesaian Sengketa, yaitu:

Pertama, Konsultasi. Konsultasi merupakan tindakan yang bersifat personal antara suatu pihak tertentu yang disebut dengan klien dengan pihak lain yang merupakan konsultan. Konsultan bertugas memberikan pendapat kepada klien untuk memenuhi keperluan dan kebutuhan klien. Tidak ada keharusan bagi klien untuk mengikuti pendapat yang disampaikan konsultan. Keputusan penyelesaian sengketa ada di tangan para pihak. Kadang, pihak konsultan juga diberikan kesempatan untuk merumuskan bentukbentuk penyelesaian sengketa yang dikehendaki oleh para pihak yang bersengketa.

Kedua, Negoisasi dan Perdamaian. Negoisasi adalah mirip dengan perdamaian sebagaimana diatur dalam Pasal 1851 sampai dengan 1864 KUH Perdata dimana perdamaian itu adalah suatu persetujuan dengan mana kedua belah pihak dengan menyerahkan, menjanjikan, atau menahan suatu barang, mengakhiri suatu perkara, yang sedang bergantung atau mencegah timbulnya suatu perkara. Persetujuan mana harus dibuat secara tertulis dengan ancaman tidak sah. Ada beberapa hal yang membedakan, yaitu pada negoisasi diberikan tenggang waktu penyelesaian paling lama 14 hari dan penyelesaian sengketa tersebut harus dilakukan dalam bentuk pertemuan langsung oleh dan di antara pihak yang bersengketa (YLBHI dan PSHK, 2007:38).

Ketiga, Mediasi. Undang-Undang No. 30 Tahun 1999 tentang Alternatif Penyelesaian Sengketa mendefinisikan mediasi sebagai kesepakatan tertulis para pihak, sengketa, atau beda pendapat diselesaikan melalui bantuan seorang atau lebih penasehat ahli 
maupun seorang mediator. Kesepakatan yang dihasilkan dalam suatu proses mediasi yang dibuat berbentuk tertulis, bersifat final dan mengikat para pihak. Selain itu, juga wajib didaftarkan di Pengadilan Negeri dalam waktu paling lama 30 hari terhitung sejak penandatanganan. Kesepakatan tersebut wajib dilaksanakan dalam waktu lama 30 hari sejak pendaftaran (YLBHI dan PSHK, 2007:38).

Keempat, Konsiliasi dan Perdamaian. UndangUndang No. 30 Tahun 1999 tentang Alternatif Penyelesaian Sengketa tidak menyebutkan konsiliasi sebagai suatu bentuk alternatif penyelesaian sengketa di luar pengadilan. Intinya, konsiliasi merupakan upaya sebelum dilakukannya proses litigasi atau bahkan bisa dilakukan dalam setiap tingkat peradilan yang sedang berjalan, baik di dalam maupun di luar pengadilan. Kecuali, untuk hal-hal atau sengketa dimana telah diperoleh suatu putusan hakim yang telah mempunyai kekuatan hukum tetap (YLBHI dan PSHK, 2007:38).

Kelima, Pendapat hukum oleh lembaga arbitrase. Berdasarkan Pasal 1 ayat (8) Undang-Undang No. 30 Tahun 1999 tentang Alternatif Penyelesaian Sengketa, pengertian dari lembaga arbitrase adalah badan yang dipilih oleh para pihak yang bersengketa untuk memberikan putusan mengenai sengketa tertentu, lembaga tersebut juga dapat memberikan pendapat yang mengikat mengenai suatu hubungan hukum tertentu dalam hal belum timbul sengketa. Sedangkan Pasal 52 menyatakan bahwa para pihak dalam suatu perjanjian berhak untuk memohon pendapat yang mengikat dari lembaga arbitrase atas hubungan hukum tertentu dari suatu perjanjian. Pendapat hukum yang diberikan oleh lembaga arbitrase bersifat mengikat (binding) oleh karena pendapat yang diberikan tersebut akan menjadi bagian yang tidak terpisahkan dari perjanjian pokok (yang dimintakan pendapat pada lembaga arbitrase tersebut). Setiap pendapat yang berlawanan terhadap pendapat hukum yang diberikan tersebut berarti pelanggaran terhadap perjanjian. Oleh karena itu, tidak dapat dilakukan perlawanan dalam bentuk upaya hukum apapun.

Keenam, Arbitrase. Berdasarkan Pasal 1 ayat (1) Undang-Undang No. 30 Tahun 1999 tentang Alternatif Penyelesaian Sengketa, pengertian arbitrase adalah cara penyelesaian suatu sengketa perdata di luar pengadilan umum yang didasarkan pada perjanjian arbitrase yang dibuat secara tertulis oleh para pihak yang bersengketa. Pada dasarnya arbitrase dapat berwujud dalam dua bentuk, yaitu klausula arbitrase yang tercantum dalam suatu perjanjian tertulis yang dibuat para pihak sebelum timbul sengketa dan suatu perjanjian arbitrase tersendiri yang dibuat para pihak setelah timbul sengketa (akta kompromosi).

\section{Penyelesaian Sengketa Perdata Mediasi}

Pengertian mediasi adalah intervensi terhadap suatu sengketa atau negoisasi oleh pihak ketiga yang dapat diterima, tidak mempunyai kewenangan untuk mengambil keputusan dalam memantu para pihak yang berselisih dalam upaya mencari kesepakatan secara sukarela dalam menyelesaikan permasalahan yang disengketakan (A.N. Susanti, 2007:1). UndangUndang No. 30 Tahun 1999 tentang Alternatif Penyelesaian Sengketa, mendefinisikan mediasi sebagai kesepakatan tertulis para pihak, sengketa, atau beda pendapat diselesaikan melalui bantuan seorang atau lebih penasehat ahli maupun seorang mediator.

Dasar hukum mediasi adalah Undang-Undang No. 4 Tahun 2004 Pasal 16 ayat (2) tentang Kekuasaan Kehakiman yang berbunyi ketentuan sebagaimana dimaksud pada ayat (1) tidak menutup usaha penyelesaian perkara perdata dengan cara perdamaian. Undang-Undang No. 30 Tahun 1999 tentang Alternatif Penyelesaian Sengketa, yang lebih mempertegas keberadaan lembaga mediasi sebagai lembaga alternatif penyelesaian sengketa. Menurut ketentuan dari Peraturan Mahkamah Agung bahwa setelah dilakukan evaluasi terhadap pelaksanaan prosedur mediasi di pengadilan berdasarkan Peraturan Mahkamah Agung Republik Indonesia No. 2 Tahun 2003 ternyata ditemukan beberapa permasalahan yang bersumber dari Peraturan Mahkamah Agung, sehingga Peraturan Mahkamah Agung Republik Indonesia No. 2 Tahun 2003 direvisi dengan maksud untuk lebih mendayagunakan mediasi yang terkait dengan proses berperkara di pengadilan. Sehingga Peraturan Mahkamah Agung No. 2 Tahun 2003 diubah menjadi Peraturan Mahkamah Agung No. 1 Tahun 2008 tentang Prosedur Mediasi di Pengadilan.

Tahapan mediasi dijelaskan tentang tahap-tahap proses mediasi sesuai dengan Peraturan Mahkamah Agung berlangsung No. 1 Tahun 2008 pada Bab III Pasal 13 tentang Penyerahan Resume Perkara dan Lama Proses Mediasi, sebagai berikut: 1. Dalam waktu paling lama 5 hari kerja setelah para pihak menunjuk mediator yang disepakati, masing-masing pihak dapat menyerahkan resume perkara kepada satu sama lain dan kepada mediator; 2. Dalam waktu paling sedikit 5 hari kerja setelah para pihak gagal memilih mediator, masing-masing pihak dapat menyerahkan resume perkara kepada hakim mediator yang ditunjuk; 3. Proses mediasi berlangsung paling lama 40 hari 
kerja sejak mediator dipilih oleh para pihak atau ditunjuk oleh Ketua Majelis Hakim sebagaimana dimaksud dalam Pasal 11 Ayat (5) dan (6); 4. Atas dasar kesepakatan para pihak, proses mediasi dapat dilakukan secara jarak jauh dengan menggunakan alat komunikasi; 5. Jangka waktu proses mediasi tidak termasuk jangka waktu pemeriksaan perkara; 6. Jika diperlukan dan atas dasar kesepakatan para pihak, mediasi dapat dilakukan secara jarak jauh dengan menggunakan alat komunikasi.

Proses mediasi dalam hal ini dibagi menjadi dua tahap yaitu pra mediasi dan tahap mediasi, yang mana sudah diatur dalam Peraturan Mahkamah Agung No. 1 Tahun 2008, yaitu:

Pertama, Pra Mediasi. Pada hari sidang yang telah ditentukan oleh para kedua belah pihak, maka majelis hakim harus mewajibkan para pihak untuk melakukan agenda mediasi dulu. Kehadiran dari pihak turut tergugat tidak menghalangi pelaksanaan mediasi, sehingga majelis hakim melalui kuasa hukum atau langsung kepada para pihak mendorong para pihak untuk berperan langsung atau aktif dalam proses mediasi. Kuasa hukum para pihak berkewajiban mendorong para pihak sendiri berperan langsung atau aktif dalam proses mediasi. Majelis Hakim wajib menunda proses persidangan perkara untuk memberikan kesempatan kepada para pihak menempuh mediasi dan hakim wajib menjelaskan prosedur mediasi dalam PERMA ini kepada para pihak yang bersengketa.

Kedua, Mediasi. Ketika para pihak sepakat untuk melakukan proses mediasi, yang mana para pihak berkehendak untuk mencapai kesepakatan penyelesaian atas sengketanya. Mediasi akan berjalan dengan kondisi-kondisi sebagai berikut: a. Mediator adalah seorang fasilitator yang akan membantu para pihak untuk mencapai kesepakatan yang dikehendaki oleh para pihak; $b$. Mediator tidak memberi nasehat atau pendapat hukum; c. Para pihak yang bersengketa dapat meminta pendapat para ahli baik dari sisi hukum lainnya selama proses mediasi berlangsung; d. Mediator tidak dapat bertindak sebagai penasehat hukum terhadap salah satu pihak dalam kasus yang sama ataupun yang berhubungan dan ia juga tidak dapat bertindak sebagai arbiter atau kasus yang sama; e. Para pihak paham agar proses mediasi dapat berjalan dengan baik maka diperlukan proses komunikasi yang terbuka dan jujur, selanjutnya segala bentuk negosiasi dan pernyataan baik tertulis maupun lisan yang dibuat dalam proses mediasi akan diperlukan sebagai informasi yang bersifat tertutup dan rahasia.

\section{Proses Penyelesaian Sengketa melalui Mediasi di Pengadilan Negeri}

Pada Pengadilan Negeri, proses penyelesaian sengketa terdiri dari dua tahap, yaitu:

Pertama, Tahap Pra Mediasi. Dalam tahap ini penggugat terlebih dahulu memasukan gugatannya ke Pengadilan Negeri, kemudian gugatan diterima oleh Pengadilan Negeri. Ketua Majelis Hakim segera menyatakan bahwa sidang terbuka untuk umum dengan mengetuk palunya di atas meja satu kali. Pada hari sidang pertama menghadirkan para pihak yang bersengketa. Sedangkan apabila pihak yang bersengketa tidak hadir. Majelis Hakim menunda jalannya persidangan kemudian memberikan kesempatan untuk pihak yang bersengketa agar hadir dalam sidang berikutnya.

Majelis Hakim dalam memeriksa perkara menerangkan bagi para pihak bahwa dalam proses pemeriksaan perkara perdata, yang mana sudah diatur dalam Peraturan Mahkamah Agung No. 1 Tahun 2008 (PERMA), mewajibkan hakim untuk menempuh jalan mediasi yang sifatnya wajib dilaksanakan pada setiap Pengadilan Negeri yang menangani perkara perdata.

Majelis Hakim dalam hal ini sebagai pemeriksa perkara perdata, telah memenuhi syarat yang terdapat dalam Pasal 2 Ayat (1), (2), (3) dan (4) Peraturan Mahkamah Agung No. 1 Tahun 2008. Pasal 2 Ayat (1) Peraturan Mahkamah Agung No. 1 Tahun 2008 menyebutkan bahwa Peraturan Mahkamah Agung ini hanya berlaku untuk mediasi yang terkait dengan proses berperkara di pengadilan. Pasal 2 Peraturan Mahkamah Agung No. 1 Tahun 2008 menyebutkan bahwa setiap hakim, mediator dan para pihak wajib mengikuti prosedur penyelesaian sengketa melalui mediasi yang diatur dalam peraturan ini. Pasal 3 Peraturan Mahkamah Agung No. 1 Tahun 2008 menyebutkan bahwa tidak menempuh prosedur mediasi berdasarkan peraturan ini merupakan pelanggaran terhadap ketentuan pasal 130 HIR dan atau pasal $154 \mathrm{Rbg}$ yang mengakibatkan putusan batal demi hukum Pasal 4 Peraturan Mahkamah Agung No. 1 Tahun 2008 menyebutkan bahwa hakim dalam pertimbangan putusan perkara wajib menyebutkan bahwa perkara yang bersangkutan telah diupayakan perdamaian melalui mediasi dengan menyebutkan nama mediator untuk perkara yang bersangkutan.

Majelis Hakim dalam hal menangani perkara perdata menerangkan pada kedua belah pihak, bahwa setiap penyelesaian sengketa perdata harus melalui mediasi terlebih dahulu. Oleh sebab itu Ketua Majelis Hakim menjelaskan adanya mediator-mediator yang 
nantinya dapat dipergunakan untuk membantu proses penyelesaian perkara perdata dengan cara mediasi atau mediator dapat dipilih sendiri dari luar pengadilan atau dari dalam pengadilan, untuk mediator dari dalam pengadilan, yang memilih adalah Majelis Hakim. Apabila para pihak ingin menggunakan mediator dari dalam Pengadilan Negeri maka para pihak tidak dipungut biaya sama sekali. Sedangkan apabila para pihak menggunakan mediator dari luar Pengadilan Negeri maka para pihak dipungut biaya sesuai dengan perkara yang ditangani. Para pihak disini diberi pilihan oleh Majelis Hakim apakah untuk mediator akan ditentukan sendiri atau menggunakan mediator yang sudah ditentukan oleh Majelis Hakim yang namanya sudah ada dalam daftar mediator Pengadilan Negeri.

Apabila para pihak ingin menggunakan mediator dari dalam Pengadilan Negeri, maka Majelis Hakim menanyakan lagi, untuk mediator apakah dapat dipilih sendiri atau dipilih oleh Ketua Majelis Hakim untuk menetapkan mediator. Dengan demikian, Majelis Hakim dalam memeriksa perkara ini telah memenuhi syarat-syarat dalam tahap pra mediasi. Hal ini sesuai dengan ketentuan dari Pasal 13 ayat (2) Peraturan Mahkamah Agung Nomor 1 Tahun 2008 yang meyebutkan bahwa dalam waktu paling lama hari kerja setelah para pihak gagal memilih mediator, masing-masing pihak dapat menyerahkan resume perkara kepada hakim mediator yang ditunjuk.

Apabila para pihak tidak menyukai atau menyetujui mediator yang telah dipilih oleh Majelis Hakim, dikarenakan para pihak tidak mengenal mediator tersebut secara mendetail, keseluruhan dan juga mungkin para pihak tersebut masih meragukan apakah mediator yang dipilih oleh majelis hakim bisa membantu mereka dalam menyelesaikan masalah yang dihadapinya dan juga bisa mendamaikan para pihak dengan cara mediasi yang telah disarankan oleh majelis hakim, maka majelis hakim tetap akan menjalankan suatu proses mediasi yang mana telah diatur dalam Peraturan Mahkamah Agung No. 1 Tahun 2008 Pasal 9 ayat (1), (2), (3), (4), (5), (6) dan (7).

Untuk memudahkan para pihak memilih mediator, Ketua Pengadilan menyediakan daftar mediator yang memuat sekurang-kurangnya 5 (lima) nama mediator dan disertai dengan latar belakang pendidikan atau pengalaman para mediator.

Ketua pengadilan menempatkan nama-nama hakim yang telah memiliki sertifikat dalam daftar mediator. Jika dalam wilayah pengadilan yang bersangkutan tidak ada mediator yang bersetifikat, semua hakim pada pengadilan yang bersangkutan dapat ditempatkan dalam daftar mediator. Mediator bukan hakim yang bersertifikat dapat mengajukan permohonan kepada ketua pengadilan agar namanya ditempatkan dalam daftar mediator pada pengadilan yang bersangkutan. Setelah memeriksa dan memastikan keabsahan sertifikat, ketua pengadilan menempatkan nama pemohon dalam daftar mediator. Setelah memeriksa dan memperbarui daftar mediator ketua pengadilan berwenang mengeluarkan nama mediator dari daftar mediator berdasarkan alasan-alasan obyektif, antara lain, karena mutasi tugas, berhalangan tetap, ketidakaktifan setelah penugasan dan pelanggaran atas pedoman perilaku.

Dalam menjadi seorang mediator diharuskan mempunyai pengetahuan yang luas khususnya dalam bidang hukum. Pengetahuan yang dimiliki oleh seorang mediator tidak hanya pengetahuan di bidang perdata tetapi dalam bidang pidana. Tetapi, dalam pengadilan jarang dijumpai mediator yang menangani kasus pidana kebanyakan mediator menangani kasus perdata.

Kedua, Tahap Mediasi. Pada hari sidang yang telah ditentukan oleh majelis hakim, majelis hakim memberikan penjelasan bahwa batas waktu yang diberikan untuk menyelesaikan proses penyelesaian sengketa perdata dengan cara mediasi adalah empat puluh (40) hari kerja, kemudian setelah empat puluh hari kerja Majelis Hakim lang-sung menentukan hari sidang untuk mendengarkan laporan dari mediator. Majelis hakim setelah selesai memberikan penjelasan kemudian menyerahkan perkara tersebut ke mediator sepenuhnya untuk diusahakan perdamaian melalui mediasi. Hasil dari kesepakatan perdamaian oleh para pihak dibacakan pada hari sidang berikutnya. Dalam hal ini mediator kemudian menempuh langkahlangkah untuk mulai mempuh proses mediasi ataupun tahap mediasi.

Langkah-langkah yang ditempuh adalah sebagai berikut: Menentukan jadwal pertemuan. Dalam pelaksanaan mediasi biasanya dilakukan pertemuan biasanya dilakukan di ruang mediasi yang sudah dipersiapkan oleh mediator. Pertemuan ini tidak boleh melebihi dari 40 hari kerja. Proses mediasi harus selesai paling lama 40 hari kerja. Hal ini sesuai dengan Peraturan Mahkamah Agung No. 1 Tahun 2008 pasal 15 ayat (1) yang berbunyi mediator wajib mempersiapkan usulan jadwal pertemuan mediasi kepada para pihak untuk dibahas dan disepakati. Dari hasil kesepakatan antara mediator dan para pihak, maka telah disepakati untuk mengadakan suatu pertemuan setiap minggunya dan tidak boleh melebihi dari 40 hari kerja. 
Kaukus adalah suatu pertemuan yang dilakukan oleh mediator yang mana pertemuan ini dilakukan secara terpisah antara penggugat dan tergugat. Pertemuan ini dilakukan terpisah dan waktunya pun berbeda karena untuk mendengarkan pendapat dari kedua belah pihak. Pertemuan ini dilakukan di ruangan yang sama yaitu ruang mediasi Pengadilan Negeri. Mediator pada awalnya bertanya pada penggugat permasalahan apa yang sedang dihadapi saat ini. Setelah mendengar penjelasan dari penggugat maka mediator menjelaskan sikap apa yang sebaiknya dilakukan oleh penggugat dan juga menjelaskan kelemahan dari penggugat. Pertemuan berikutnya mediator mengadakan pertemuan dengan tergugat dan menanyakan hal yang sama seperti pada saat mediator menanyakan pada pihak penggugat. Mediator disini memberikan penjelasan bahwa penggugat disini menderita kerugian yang cukup besar, karena uang yang seharusnya digunakan untuk usahanya, sekarang usahanya menjadi terhambat dan perputaran modalnya secara otomatis menjadi terhambat. Mediator juga menjelaskan apabila masalah ini tidak segera cepat diselesaikan maka sulit dilakukannya perdamaian. Mediator tidak akan membela masing-masing pihak melainkan mediator disini adalah seorang yang mempunyai sikap yang netral dan diharapkan dapat menyelesaikan kemungkinan penyelesaian sengketa. Hal ini sesuai dengan Peraturan Mahkamah Agung Nomer 1 Tahun 2008 pasal 15 ayat (3).

Dalam agenda pertemuan kedua belah pihak diantaranya: a. Pertemuan Pertama, pada saat mediator telah menyelesaikan kaukus, lalu mediator melaksanakan tugasnya yaitu mempertemukan kedua belah pihak dalam waktu dan tempat yang sama mediator menerangkan fakta-fakta yang sesuai pada pertemuan pertama yang dihadiri oleh kedua belah pihak; b. Pertemuan Kedua apabila ada salah satu pihak yang tidak hadir dan hanya diwakili oleh kuasa hukumnya, maka mediator disini harus berusaha menekankan pada kedua belah pihak agar para pihak yang bersengketa langsung hadir, tidak hanya kuasa hukumnya saja yang hadir ataupun kuasa hukum hadir hanya saja sebatas mendampingi. Hal ini dilakukan agar tidak terjadi kesalahpahaman dan juga tidak mempersulit serta menghambat terjadinya kesepakatan antara kedua belah pihak. Oleh sebab itu mediator disini berpesan agar yang hadir tidak hanya kuasa hukumnya tetapi kedua belah pihak yang sedang bersengketa juga hadir, sehingga pada saat dilakukan proses mediasi, yang berdamai adalah para pihak yang bersengketa bukan para kuasa hukumnya. Jika pihak yang bersengketa hadir, maka pertemuan ini masih membahas dan melanjutkan perundingan pada pertemuan-pertemuan yang telah lalu; c. Pertemuan Ketiga ini mediator membantu para pihak untuk menyelesaikan proses penyelesaian sengketa ini. Akhirnya, setelah diperoleh kesepakatan yang akan menanggung semua perkara, kemudian dilanjutkan untuk membahas konsep-konsep apa yang akan dilakukan untuk mencapai suatu kesepakatan dalam melakukan proses mediasi sebelumnya. Mediator disini meminta agar kedua belah pihak agar mempersiapkan rancangan-rancangan yang nantinya akan ditandatangani. Kemudian para pihak diminta agar mempersiapkan untuk pertemuan berikutnya; $d$. Pertemuan Keempat merupakan pertemuan terakhir yang diadakan dalam suatu proses mediasi. Pada pertemuan ini membahas tentang hasil kesepakatan dari masing-masing pihak yang sebelumnya sudah dipersiapkan. Selain para pihak yang membuat kesepakatan, mediator juga membuat kesepakatan sendiri. Hasil kesepakatan kedua belah pihak tersebut kemudian diserahkan kepada mediator untuk diperiksa. Hasil dari kesepakatan ini telah ditentukan dan tercantum dalam Peraturan Mahkamah Agung No. 1 Tahun 2008 Pasal 17 Ayat (3). Hasil dari kesepakatan antara kedua belah pihak dibaca oleh mediator untuk diperiksa apakah ada kesalahan dalam hasil kesepakatan tersebut. Apabila ada suatu kesalahan maka mediator menjelaskan kesalahan apa yang ada dalam kesepakatan tersebut. Mediator juga berorientasi sesuai dengan ilmu pengetahuannya untuk menunjukan suatu hasil kesepakatan yang sebenarnya yang ada dalam suatu proses penyelesaian sengketa dengan cara mediasi, setelah para pihak mengetahui hasil kesepakatan yang benar maka para pihak masingmasing harus menandatangani hasil kesepakatan tersebut.

Mediator setelah menyelesaikan tugasnya dalam menyelesaikan mediasi, maka harus melaporkan hasil mediasi,setelah hasil mediasi tercapai maka mediator harus melaporkan kepada majelis hakim dan menyerahkan hasil laporan tersebut berupa laporan tertulis, dan juga melampirkan hasil kesepakatan kedua belah pihak yang telah ditandatangani para pihak apabila suatu proses mediasi telah berhasil dilakukan. Apabila suatu mediasi tersebut tidak berhasil maka harus dilaporkan pula kepada majelis hakim dalam memeriksa perkara tersebut dengan cara tertulis. Hal ini tercantum dalam Peraturan Mahkamah Agung No. 1 Tahun 2008 dalam pasal 18 ayat (1) yang berbunyi: Jika setelah batas waktu maksimal 40 (empat puluh) hari kerja sebagaimana dimaksud dalam pasal 13 ayat (3), para pihak tidak mampu 
menghasilkan kesepakatan atau karena sebab-sebab yang terkandung dalam pasal 15, mediator wajib menyatakan secara tertulis bahwa proses telah gagal dan memberitahukan kegagalan kepada hakim.

Mediator sebelum memberikan laporan kepada majelis hakim mediator memberikan penjelasan kepada para pihak meskipun mediasi telah gagal dilakukan tetapi kedua belah pihak bisa melakukan perdamaian dalam persidangan. Hal ini dilakukan karena pada saat majelis hakim menerima hasil laporan dari mediator, laporan tersebut dikembalikan lagi. Majelis hakim dalam dalam hal ini melakukan pemeriksaan sesuai dengan hukum acara perdata. Dalam suatu persidangan yang dilakukan oleh majelis hakim, majelis hakim disini menanyakan pada kedua belah pihak dan menawarkan serta menyarankan apakah mereka para pihak tersebut bisa melakukan mediasi. Dalam hal ini majelis hakim telah menerapkan dan menyesuaikan sesuai dengan pasal 130 HIR yang mengupayakan untuk melakukan perdamaian bagi para pihak yang bersengketa.

Setelah hasil laporan yang gagal diserahkan pada majelis hakim, lantas laporan tersebut dimusnahkan atau bisa disimpan sebagai arsip bagi mediator. Perlu diketahui, majelis hakim tidak mengetahui tentang hasil laporan mediator sebelum diserahkan ke majelis hakim. Dalam hal ini mediator tidak bisa menjadi saksi dalam perkara yang ditangani dan tidak bisa dipertanggung jawabkan. Ketentuan ini diatur dalam Peraturan Mahkamah Agung No. 1 Tahun 2008 Pasal 18 ayat (2), Pasal 19 ayat (1), (2), (3) dan ayat (4).

\section{Kerancuan Proses Mediasi}

Dari serangkaian proses mediasi di pengadilan, masih mengandung sejumlah kerancuan terutama prosedur pra mediasi yang diatur di dalam Peraturan Mahkamah Agung No. 1 Tahun 2008. Adapun kerancuan yang dimaksud antara lain:

Pertama, mengenai kewajiban para pihak untuk memilih mediator, atau dalam hal ini dapat juga dikatakan kewajiban untuk memilih proses mediasi. Kerancuan ini muncul terutama ketika para pihak memilih cara berdamai dengan mekanisme negoisasi, para pihak tidak mau menggunakan mediator sebagaimana yang dimungkinkan oleh Pasal 130 dan Pasal 131 HIR. Sementara di dalam Peraturan Mahkamah Agung No. 1 Tahun 2008 pilihan untuk memilih upaya perdamaian hanya terbatas pada mediasi, padahal masih ada mekanisme perdamaian yang lain seperti negoisasi;

Kedua, mengenai waktu harus dikeluarkan perintah majelis dan kepada para pihak untuk menempuh proses mediasi dan harus ditetapkannya penundaan persidangan, dalam kaitannya dengan waktu pemilihan mediator. Dalam hal ini, penundaan persidangan harus dilakukan pada saat sidang pertama yakni setelah majelis hakim memerintahkan para pihak untuk terlebih dahulu menempuh mediasi, sementara pada saat itu para pihak belum menunjuk mediator. Pada sisi yang lain, permasalahan kapan para pihak berhasil menunjuk mediator memiliki implikasi pada lamanya rentang waktu proses mediasi dapat dilakukan. Kekurangan tersebut berpotensi menimbulkan hambatan dalam implementasinya ditemukan dalam Peraturan Mahkamah Agung No. 1 Tahun 2008 Pasal 7 Ayat (5) bahwa hakim wajib menunda proses persidangan perkara untuk memberikan kesempatan kepada para pihak menempuh proses mediasi. Penundaan persidangan tersebut dimaksudkan untuk memberikan kesempatan kepada para pihak untuk menempuh proses mediasi. Penundaan persidangan ini adalah mutlak, hakim tidak boleh melakukan pemeriksaan perkara.

Hal tersebut konsekuensi logis dari adanya kewajiban hakim untuk mendahulukan penyelesaian sengketa melalui mediasi. Penundaan persidangan dalam Peraturan Mahkamah Agung No. 2 Tahun 2003 maupun Peraturan Mahkamah Agung No. 1 Tahun 2008, tidak mengatur dengan jelas berapa lama hakim harus menunda persidangan, akan tetapi jika dilihat peruntukannya maka lamanya penundaan persidangan dapat dilihat dari batas paling lama proses mediasi sudah harus selesai. Adapun mengenai lamanya waktu yang dapat diberikan untuk menyelesaikan sengketa melalui mediasi, Peraturan Mahkamah Agung No. 1 Tahun 2008 menjelaskan pada Pasal 13 Ayat (3) dan (4), bahwa proses mediasi berlangsung paling lama 40 (empat puluh) hari kerja sejak mediator dipilih oleh para pihak atau ditunjuk oleh Ketua Majelis Hakim dan dapat diperpanjang paling lama 14 (empat belas) hari sejak berakhirnya masa 40 (empat puluh) hari tersebut. Kelemahan ini dikuatirkan akan berimplikasi terhadap lamanya proses berperkara, karena juga disebutkan dalam Pasal 13 Ayat (5) Peraturan Mahkamah Agung tersebut, yaitu jangka waktu proses mediasi tidak termasuk jangka waktu pemeriksaan perkara, sehingga tujuan untuk mengoptimalkan peran lembaga peradilan tingkat pertama. Kendala yang lainnya adalah jika para pihak tidak mentaati perintah hakim, dalam arti bahwa sampai batas waktu yang disediakan habis (batas waktu maksimal 40 hari kerja), para pihak tidak mau menempuh proses mediasi. Jika masalah ini yang terjadi, hakim dapat menganggap bahwa proses perdamaian atau mediasi 
telah gagal, sehingga pada tahap selanjutnya hakim akan memeriksa perkara dan memutuskannya berdasarkan hukum acara perdata biasa.

Proses mediasi di pengadilan masih memiliki sejumlah kelemahan yaitu: 1 . Institusi mediasi tersebut tidak bisa menjangkau sengketa-sengketa yang tidak diajukan ke pengadilan, dan 2. Institusi mediasi yang dimaksud kurang efektif karena biasanya baru bisa bekerja setelah suatu sengketa itu menjadi sengketa yang sulit didamaikan. Dikatakan demikian karena perkara yang dibawa ke pengadilan biasanya karena sudah sedemikian sulit didamaikan.

\section{PENUTUP}

\section{Kesimpulan}

Berdasarkan uraian di atas, maka diperoleh kesimpulan adalah bahwa mediasi dalam perkara perdata berdasarkan Peraturan Mahkamah Agung No. 1 Tahun 2008 tidak efektif di dalam penyelesaian perkara perdata di pengadilan dari sudut waktu, sehingga akan memperpanjang waktu, yang pada akhirnya tidak bisa memenuhi asas peradilan sederhana, cepat, dan biaya ringan. Di samping itu, pengaturan mediasi menurut Peraturan Mahkamah Agung No. 1 Tahun 2008 kurang efektif, karena mediasi hanya untuk melaksanakan mekanisme formalnya, tidak berupaya untuk menemukan solusi terbaik dalam penanganan perkara, dan sengketa yang diajukan ke pengadilan adalah sengketa yang sudah sangat sulit untuk didamaikan, jadi keberhasilan mediasi tergantung itikad baik para pihak untuk menemukan solusi terbaik.

\section{Rekomendasi}

Berdasarkan uraian di atas, dapat dikemukakan rekomendasi sebagai berikut: a. hendaknya pihak yang bersengketa dalam sengketa perdata menggunakan mekanisme mediasi untuk menyelesaikan dengan itikad baik untuk mencapai kesepakatan win-win solution, sebelum memutuskan untuk menempuh upaya penyelesaian litigasi; 2. adanya keharusan para pihak yang bersengketa di Pengadilan Negeri untuk menempuh proses mediasi terlebih dahulu setelah seseorang mengajukan perkaranya ke pengadilan, dengan mediator yang ditunjuk oleh pengadilan maupun oleh para pihak sendiri, telah menunjukkan bahwa Mahkamah Agung sangat responsif terhadap proses mediasi, dan sifat responsif ini menandakan bahwa proses penyelesaian sengketa melalui mediasi merupakan proses penyelesaian sengketa yang jauh lebih baik daripada proses peradilan serta berimplikasi terjadinya proses peradilan sederhana, cepat, dan biaya ringan; dan 3. perlu dukungan konkret dari institusi formal pengadilan yaitu Mahkamah Agung RI untuk melakukan pengawasan terhadap proses mediasi yang diamanatkan dalam Peraturan Mahkamah Agung No. 1 Tahun 2008 dan juga melakukan kebijakan responsif dalam pembaharuan di bidang hukum khususnya dalam penyelesaian sengketa.

\section{DAFTAR PUSTAKA}

\section{Buku:}

Harahap, Yahya, 2005, Kedudukan, Kewenangan dan Acara Pengadilan Agama UU No. 7 Tahun 1989, Jakarta: Sinar Grafika.

Rambe, Ropaun, 2006, Hukum Acara Perdata Lengkap, Jakarta: Sinar Grafika.

Susanti, A.N., 2007, Naskah Akademis Mediasi. Jakarta: Mahkamah Agung RI.

YLBHI dan PSHK, 2007, Panduan Bantuan Hukum di Indonesia: Pedoman Anda Memahami dan Menyelesaikan Masalah Hukum, Jakarta: Yayasan Obor Indonesia.

\section{Peraturan Perundang-undangan:}

Herziene Inlands Reglement (HIR).

PERMA No. 1 Tahun 2008 tentang Prosedur Mediasi di Pengadilan.

\section{Website:}

Metronews.com, "LSI: Penegakan Hukum di Indonesia Buruk", http://metrotvnews.com/read /news/2012/01/09/77911/LSI-Penegakan-Hukumdi-Indonesia-Buruk, 9 Januari 2012. 